Skin

Pharmacology
and
Physiology
Skin Pharmacol Physiol 2011;24:54

DOI: $10.1159 / 000319316$

Published online: September 16, 2010

\title{
7th Dermadays, Witten, April 21-22, 2010
}

On the occasion of the 20th anniversary of the Dermatronnier Institute for Experimental Dermatology at the University of Witten/Herdecke, the 7th Dermadays took place in Witten on April 21 and 22, 2010. The Dermadays are an opportunity for the institute to inform friends and partners about the work accomplished in the last few years as well as to thank the invited guests for their cooperation. The extensive scientific programme of this year's Dermadays, which was predominantly put together by partners of the institute, offered a large variety of topics. They ranged from the histology of the skin, the neurophysiology of itching and the penetration problems of active ingredients to questions about and the current situation of in vitro sun protection, the logistics for skin-physiological measurements of weightlessness, the detection of substances in nutritional supplements and the possibilities to apply photo-acoustics in photodermatological research.

This varied programme was complemented by an opening presentation of the institute's director, Prof. Tronnier, with critical reflections on the different quality of active agents in cosmetics and the application focus in the field of anti-aging. Prof. Heinrich, the research director, presented examples of the institute's research with study results, mainly with regard to modern methodological supplements and alternatives. Ms. Wiebusch, who is in charge of the laboratory, reported about first tests with a method for determining the elasticity of the skin which supplements the Cutometer measurements. The scientific programme was rounded off by a poster exhibition on research projects of the past 3 years. These posters have been or are going to be presented at international conferences.

The festive dinner in the Museum für Kunst- und Kulturgeschichte der Stadt Dortmund (Museum for Art and Cultural History of the City of Dortmund) with a guided tour and the presentation of a selection of exhibits as well as a musical programme, 'Einmal Klassik und zurück', presented in a virtuoso manner, was a relaxing highlight for the 50 participants of the symposium.

\section{KARGER}

Fax +41613061234 E-Mail karger@karger.ch www.karger.com (c) 2010 S. Karger AG, Base

1660-5527/11/0241-0054\$38.00/0 